\title{
Schoenheimer effect explained - feedback regulation of cholesterol synthesis in mice mediated by Insig proteins
}

\author{
Luke J. Engelking, ${ }^{1}$ Guosheng Liang, ${ }^{1}$ Robert E. Hammer ${ }^{2}$ Kiyosumi Takaishi, ${ }^{1}$ Hiroshi Kuriyama, ${ }^{1}$
} Bret M. Evers, ${ }^{1}$ Wei-Ping Li, ${ }^{3}$ Jay D. Horton, ${ }^{1,4}$ Joseph L. Goldstein, ${ }^{1}$ and Michael S. Brown ${ }^{1}$

${ }^{1}$ Department of Molecular Genetics, ${ }^{2}$ Department of Biochemistry, ${ }^{3}$ Department of Cell Biology, and ${ }^{4}$ Department of Internal Medicine, University of Texas Southwestern Medical Center, Dallas, Texas, USA.

\begin{abstract}
End-product feedback inhibition of cholesterol synthesis was first demonstrated in living animals by Schoenheimer 72 years ago. Current studies define Insig proteins as essential elements of this feedback system in mouse liver. In cultured cells, Insig proteins are required for sterol-mediated inhibition of the processing of sterol regulatory element-binding proteins (SREBPs) to their nuclear forms. We produced mice with germline disruption of the Insig2 gene and Cre-mediated disruption of the Insig1 gene in liver. On a chow diet, these double-knockout mice overaccumulated cholesterol and triglycerides in liver. Despite this accumulation, levels of nuclear SREBPs and mRNAs for SREBP target genes in lipogenic pathways were not reduced. Whereas cholesterol feeding reduced nuclear SREBPs and lipogenic mRNAs in wild-type mice, this feedback response was severely blunted in the double-knockout mice, and synthesis of cholesterol and fatty acids was not repressed. The amount of HMG-CoA reductase protein was elevated out of proportion to the mRNA in the double-knockout mice, apparently owing to the failure of cholesterol to accelerate degradation of the enzyme. These studies indicate that the essential elements of the regulatory pathway for lipid synthesis function in liver as they do in cultured cells.
\end{abstract}

\section{Introduction}

In 1933, Rudolph Schoenheimer, a physician then working in Germany, performed a metabolic balance study in mice and observed that the animals synthesized large amounts of cholesterol when fed a low-cholesterol diet and that synthesis stopped when the mice were fed cholesterol (1). This experiment provided the first evidence for end-product feedback regulation of a biosynthetic pathway, a discovery that predated by 2 decades the demonstration of end-product feedback inhibition in bacteria and prefigured much of modern molecular biology and metabolic science. With the advent of radioisotopes, Gordon Gould showed in the early 1950s that the cholesterol-feedback system operated in the liver of living animals $(2,3)$.

In subsequent years many details of cholesterol feedback were elucidated, including the identification of HMG-CoA reductase as a highly regulated rate-controlling reaction (reviewed in ref. 4). However, the fundamental molecular mechanism by which liver cells sense cholesterol and use that information to regulate cholesterol production remained obscure until recent studies were conducted in cultured mammalian cells.

The cultured cell studies showed that transcription of HMG-CoA reductase and other genes in the cholesterol biosynthetic pathway is dependent upon sterol regulatory element-binding proteins (SREBPs), a family of sterol-regulated, membrane-bound transcription factors (5). The SREBPs begin life as integral proteins of

Nonstandard abbreviations used: CREB, cAMP-responsive element-binding protein; dpc, day(s) post coitum; FDP, farnesyl diphosphate; f/f, flox/flox; L-Insig1-/ conditional deficiency of Insig1 in liver; nSREBP, nuclear form of SREBP; pIpC, polyinosinic acid-polycytidylic acid; PSREBP, precursor of SREBP; SREBP, sterol regulatory element-binding protein.

Conflict of interest: The authors have declared that no conflict of interest exists.

Citation for this article: J. Clin. Invest. 115:2489-2498 (2005).

doi:10.1172/JCI25614. the ER. To gain access to nuclear DNA, the SREBPs must move in vesicles to the Golgi complex, where they are processed proteolytically $(6,7)$. ER-to-Golgi complex transport is mediated by Scap, a polytopic ER membrane protein that forms complexes with newly synthesized SREBPs. Scap acts as a nucleation site for COPII proteins, which mediate the incorporation of the Scap-SREBP complex into COPII-coated vesicles that move to the $\operatorname{Golgi}$ complex $(8,9)$.

In cultured cells, feedback inhibition of cholesterol synthesis is mediated by Insigs, polytopic ER membrane proteins that serve as anchors $(10,11)$. When the cholesterol content of ER membranes rises, cholesterol binds to a membrane-embedded region of Scap designated the sterol-sensing domain (12), thereby causing a conformational change $(13,14)$. The altered Scap binds to Insigs, thus preventing exit of the Scap-SREBP complex from the ER. As a result, the nuclear content of processed SREBPs declines, the cholesterol biosynthetic genes are not transcribed actively, and cholesterol synthesis ceases. When cultured cells are depleted of cholesterol, Scap undocks from Insigs and the Scap-SREBP complex then moves to the Golgi complex for processing and activation of cholesterol synthesis.

Insigs have a second action in the feedback regulation of cholesterol synthesis, namely, they mediate the rapid proteolytic degradation of HMG-CoA reductase $(15,16)$. Like Scap, HMG-CoA reductase is synthesized on ER membranes. The catalytic domain of the enzyme is attached to the membrane by virtue of an $\mathrm{NH}_{2}$ terminal segment that contains 8 membrane-spanning helices (17, 18). Like Scap, the membrane-embedded portion of HMG-CoA reductase contains a sterol-sensing domain (19). When sterols accumulate in ER membranes, they trigger the binding of HMGCoA reductase to Insigs, initiating a process by which HMG-CoA reductase is ubiquitinated and degraded $(15,16)$. When cells are depleted of sterols, HMG-CoA reductase has an extended lifetime 
A

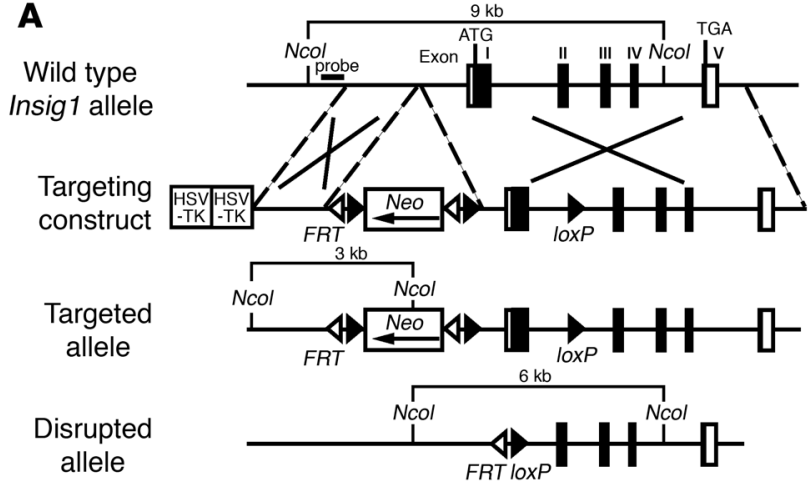

B

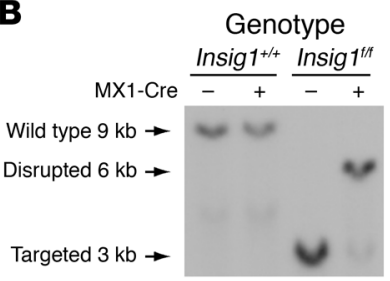

C Genotype
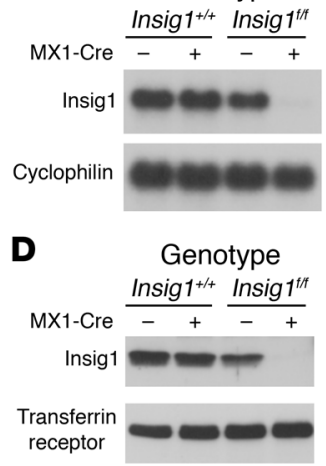

E

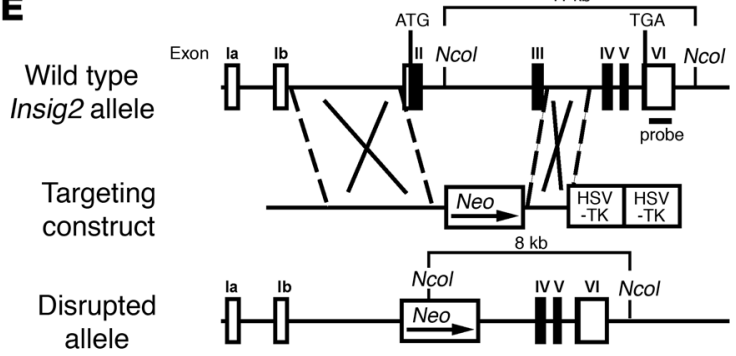

F

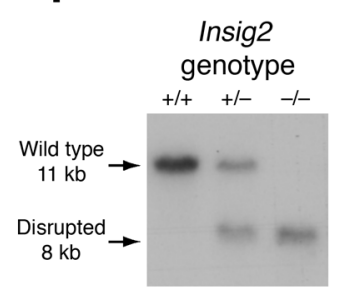

G

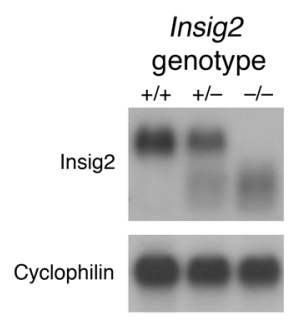

H

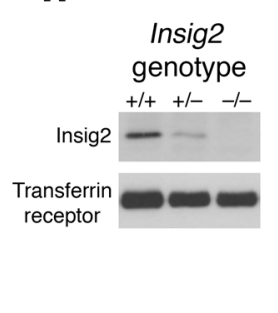

Figure 1

Targeted disruption of Insig1 and Insig2 genes in mice. (A) Schematic of Insig1 gene-targeting strategy. Cre-mediated excision of the sequences between loxP sites deletes exon 1. The location of the probe used for Southern blot analysis is denoted by the horizontal filled rectangle labeled "probe." (B) Representative Southern blot analysis of Ncol-digested DNA from livers of mice with the indicated genotypes that were treated with 4 intraperitoneal injections of plpC (300 $\mu \mathrm{g} /$ injection). (C) Northern blot analysis of hepatic RNA of mice indicated in B. Total RNA from liver was pooled, and $20-\mu \mathrm{g}$ aliquots were subjected to electrophoresis and blot hybridization with ${ }^{32} \mathrm{P}$-labeled cDNA probes for mouse Insig1 and mouse cyclophilin. (D) Immunoblot analysis of livers of mice indicated in B. Liver membrane fractions were prepared as described in Methods, and aliquots $(45 \mu \mathrm{g})$ were subjected to SDS-PAGE and immunoblot analysis. (E) Schematic of Insig2 gene-targeting strategy. The Insig2 allele was disrupted by replacement of exons II and III of the Insig2 gene with a poll/sneopA expression cassette. The DNA probe used for Southern blot analysis is denoted by the horizontal filled rectangle labeled "probe." (F) Representative Southern blot analysis of Ncol-digested tail DNA of the offspring from mating of Insig2+/- mice. (G) Northern blot analysis of hepatic RNA of mice described in F. Total RNA from livers of mice was subjected to electrophoresis and blot hybridization with ${ }^{32} \mathrm{P}$-labeled cDNA probes for mouse Insig2 and mouse cyclophilin. (H) Immunoblot analysis of liver membranes from mice with the indicated Insig2 genotype, as described above.

and the amount of active enzyme increases; this contributes to an increase in cholesterol synthesis in sterol-depleted cells (20).

Two mammalian Insig genes have been identified, Insig1 and Insig2 (11). They encode highly similar proteins (59\% identity). In cultured cells, the 2 Insig genes have redundant functions. Reduction of both Insig mRNAs, as achieved with RNA interference $(14,16)$ or by mutational inactivation in hamster cells (21), leads to an increase in nuclear SREBPs (nSREBPs). More important, nSREBPs fail to decline after sterol treatment. The reduction in both Insig1 and Insig2 causes the level of HMG-CoA reductase protein to be elevated to an even greater extent than the level of reductase mRNA, owing to a failure of sterols to stimulate reductase degradation. Mutant hamster cells that are deficient in Insig 1 but not Insig2 show partial defects in regulation of reductase degradation and SREBP processing (22).

The regulatory system in mouse liver is more complicated because the 2 Insig genes are under reciprocal regulation (11). Expression of Insig1 in liver is dependent upon nSREBPs, especially 1 isoform, designated SREBP-1c. Transcription of the SREBP-1c gene is induced by insulin (23). Thus, Insig1 mRNA disappears during fasting when insulin levels are low and SREBP-1c is repressed. Conversely, Insig1 mRNA rises to high levels upon refeeding, when insulin rises and nSREBP-1c increases (24). In direct contrast, the
Insig2 gene in liver is transcribed by a hepatocyte-specific promoter (Insig2a) that is repressed by insulin (24). Under fasting conditions, when Insig1 falls, Insig2 rises. Upon refeeding, the 2 proteins are switched: Insig2 disappears and is replaced by Insig1.

A regulatory role for Insig proteins in liver was inferred from experiments in transgenic mice that overexpress Insig1 (25). In these mice the content of nSREBPs was reduced, and the target lipogenic mRNAs were all decreased. nSREBPs and target mRNAs declined further in a supersensitive fashion in response to cholesterol feeding. These experiments demonstrated that Insig 1 acts in liver when it is overexpressed, but they did not indicate whether Insigs play a role under normal conditions. In the current paper, we have addressed these questions by disrupting the genes for Insig1 and Insig2, together or separately, in livers of mice. The results indicate that Insigs are essential components of the cholesterol-feedback system that was defined by Schoenheimer and Gould.

\section{Results}

Figure 1A shows the gene-targeting strategy for mouse Insig1. A neomycin resistance cassette (neo) flanked by loxP and frt sites was inserted into the 5'-flanking region of the Insig1 gene. An additional loxP site was inserted into the first intron. Cre-mediated recombination 
Table 1

Segregation of disrupted Insig1 and Insig2 alleles in mice

\begin{tabular}{|c|c|c|c|c|c|c|c|c|}
\hline Mating genotype & $\begin{array}{l}\text { Age of } \\
\text { offspring }\end{array}$ & $\begin{array}{l}\text { No. of } \\
\text { litters }\end{array}$ & $\begin{array}{l}\text { No. of } \\
\text { offspring }\end{array}$ & $\begin{array}{l}\text { Insig1+/+ } \\
\text { Insig2+/+ }\end{array}$ & $\begin{array}{l}\text { Insig1+/- } \\
\text { Insig2-/- }\end{array}$ & $\begin{array}{l}\text { Insig1-/- } \\
\text { Insig2+/- }\end{array}$ & $\begin{array}{l}\text { Insig1-/- } \\
\text { Insig2-/- }\end{array}$ & $\begin{array}{l}\text { All other } \\
\text { genotypes }\end{array}$ \\
\hline 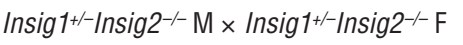 & $12.5 \mathrm{dpc}$ & 20 & 168 & NA & $81(84)$ & NA & $41(42)$ & $46(42)$ \\
\hline 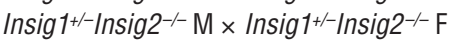 & $18.5 \mathrm{dpc}$ & 14 & 112 & NA & $58(56)$ & NA & $23(28)$ & $31(28)$ \\
\hline 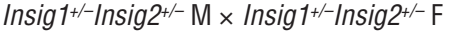 & Adult & 11 & 95 & $7(6)$ & $11(12)$ & $3(12)$ & $0(6)^{B}$ & $74(59)$ \\
\hline
\end{tabular}

Genotype was determined by PCR analysis of DNA prepared from embryonic tissues at the indicated dpc or from tails of adult mice. ${ }^{A}$ Other genotypes

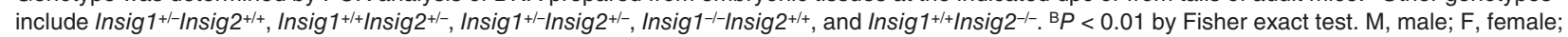
NA, not applicable.

removes exon 1 of Insig1. Mice carrying the floxed Insig1 allele were bred to transgenic mice that express Cre recombinase driven from the interferon-responsive $M X 1$ promoter ( $M X 1$-Cre) to derive mice homozygous for the floxed Insig1 allele and hemizygous for the MX1Cre transgene (Insig1 ${ }^{\mathrm{f} / \mathrm{f}} M X 1-\mathrm{Cre} ; f / f$ denotes flox/flox). When injected 4 times with a synthetic double-stranded ribonucleotide polyinosinic acid-polycytidylic acid ( $\mathrm{pI} \mathrm{PC}$ ), these mice produced interferon, which activates the $M X 1$ promoter, thereby producing the Cre recombinase in liver and other tissues (26). Figure $1 \mathrm{~B}$ shows Southern blot analysis of $\mathrm{NcoI}$-digested genomic DNA extracted from the livers of PIpC-treated mice of the indicated genotypes and probed with a 299-bp genomic fragment at the 5 ' end of the Insig1 gene. In wild-type mice and mice hemizygous for the MX1-Cre transgene, a 9-kb band is observed that is unaffected by the expression of the Cre transgene. In Insig $1^{\mathrm{f} / \mathrm{f}}$ mice, a 3 -kb band is observed which is markedly decreased in Insig $1^{\mathrm{f} / \mathrm{f}} \mathrm{MX}$-Cre mice and is replaced by a $6-\mathrm{kb}$ band that results from recombination between loxP sites. This recombination eliminates sequences encoding the first 119 of the 259 amino acids of Insig1.

Figure 1, C and D, shows the expression of Insig1 by Northern blot analysis of total RNA and by immunoblotting of membrane proteins prepared from the same livers as those represented in Figure 1B. Levels of hepatic Insig1 mRNA and protein were identical in wild-type and MX1-Cre mice and were reduced by $20 \%$ in Insig $1^{\mathrm{f} / \mathrm{f}}$ mice, perhaps owing to transcriptional interference from the neo cassette. Insig 1 mRNA and protein declined by more than $90 \%$ in Insig1 ${ }^{\mathrm{f} / \mathrm{f}} \mathrm{MX}$ 1-Cre mice injected with $\mathrm{pIpC}$ as compared with that in wild-type mice. In other studies using animals that were not injected with $\mathrm{pIpC}$, the expression of Insig $1 \mathrm{mRNA}$ in Insig $1^{\mathrm{f} / \mathrm{f}} \mathrm{MX} 1$-Cre was the same as in Insig $1^{\mathrm{f} / \mathrm{f}}$ mice (data not shown).

\section{Figure 2}

Immunoblot (A) and lipid analysis (B) of livers from control and Insigdeficient mice. The mice used in this figure are the same as those compared in Table 2. (A) Immunoblot analysis from nuclear extract and membrane fractions obtained from mice with the following 4 geno-

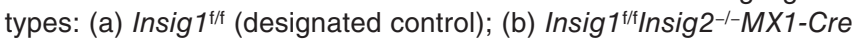

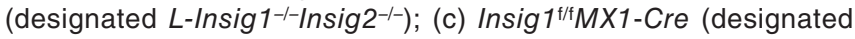

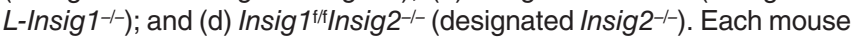
was treated with 4 intraperitoneal injections of plpC (300 $\mu \mathrm{g} /$ injection), and tissues were obtained 14 days after the final injection. Livers $(n=6)$ were separately pooled, and $45-\mu \mathrm{g}$ aliquots of the pooled membrane and nuclear extract fractions were subjected to SDS-PAGE and immunoblot analysis. CREB protein and the transferrin receptor were used in the immunoblots as loading controls for the nuclear extract and membrane fractions, respectively. P, pSREBP; N, nSREBP. (B) Hepatic cholesterol and triglyceride content of control and Insig-deficient livers. Each bar represents the mean \pm SEM of data from 6 mice.
Figure 1E shows the strategy for germline targeting of mouse Insig2. Exons 2 and 3 of Insig 2 were replaced by a neo cassette, which eliminated sequences encoding the first 123 of 225 amino acids of Insig2. Mating between Insig $2^{+/-}$mice yielded Insig2 $2^{+/}$, Insig $2^{+/-}$, and Insig2 $-/-$ mice at the expected 1:2:1 ratio. Figure $1 \mathrm{~F}$ shows representative Southern blots of NcoI-digested genomic DNA extracted from the tails of Insig2 $2^{+/}$, Insig2 $2^{+/}$, and Insig2 $2^{-/}$littermates probed with a 505-bp genomic fragment containing exon 6 of the Insig2 gene. The expression of Insig2 mRNA and protein in these mice is shown in Figure 1, G and $\mathrm{H}$, respectively. When the RNA was probed with a cDNA containing part of the 3 -untranslated region of Insig2, the result is an aberrant transcript in Insig2 $2^{+/-}$and Insig2 $2^{-/-}$ mice, perhaps owing to a transcript initiating in exons $1 \mathrm{a}$ or $1 \mathrm{~b}$ and splicing directly into exons 4,5 , or 6 (Figure $1 G$ ). In such a transcript, the first available inframe methionine is located in exon 5. If translated, this transcript would yield a peptide of only 23 amino acids. Levels of hepatic Insig2 protein, as detected by immunoblotting with antiserum raised against full-length mouse Insig2, were
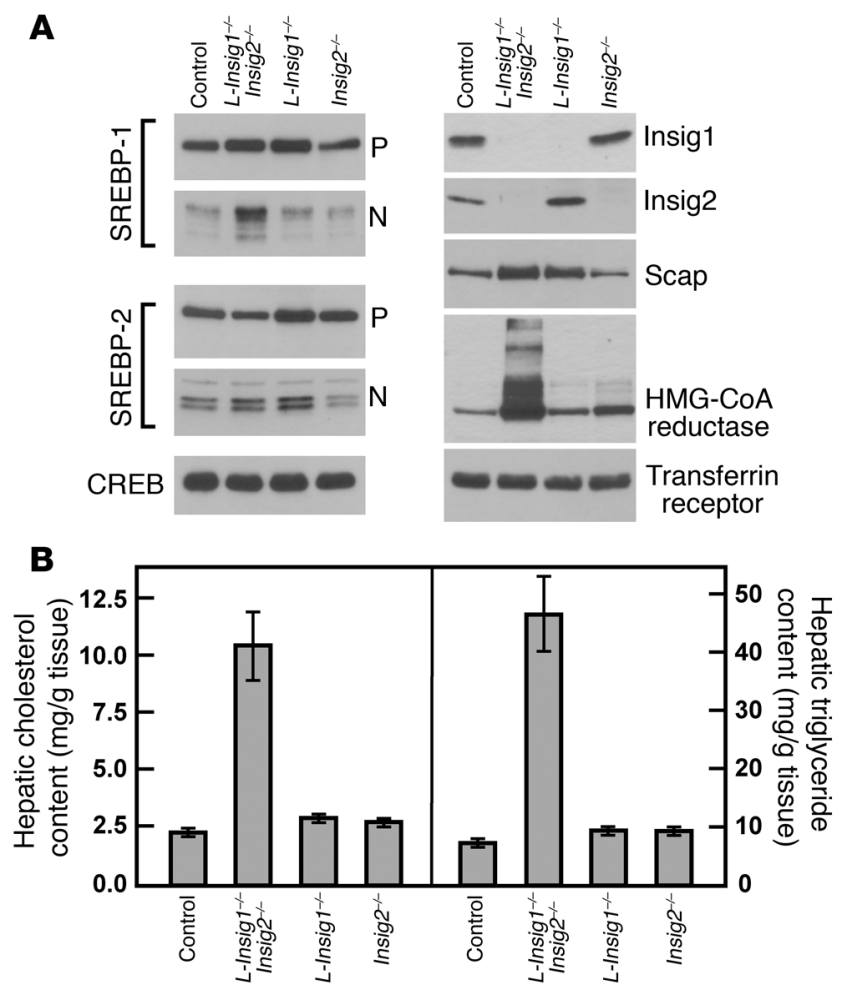
Table 2

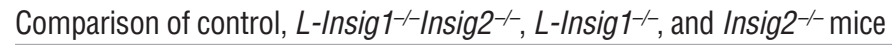

\begin{tabular}{lcccc} 
Parameter & Control & L-Insig1-/-Insig2 - - & L-Insig1-/ & Insig2-/ \\
Number of mice & 6 & 6 & 6 & 6 \\
Body weight $(\mathrm{g})$ & $26.6 \pm 1.0$ & $24.5 \pm 0.9$ & $27.6 \pm 1.2$ & $25.4 \pm 0.5$ \\
Liver weight $(\mathrm{g})$ & $1.39 \pm 0.05$ & $1.42 \pm 0.07$ & $1.43 \pm 0.09$ & $1.37 \pm 0.05$ \\
Plasma cholesterol $(\mathrm{mg} / \mathrm{dl})$ & $81 \pm 3$ & $110 \pm 7^{\mathrm{A}}$ & $88 \pm 4$ & $75 \pm 6$ \\
Plasma triglycerides $(\mathrm{mg} / \mathrm{dl})$ & $76 \pm 8$ & $55 \pm 5^{\mathrm{A}}$ & $68 \pm 5$ & $65 \pm 6$ \\
Plasma insulin $(\mathrm{ng} / \mathrm{ml})$ & $1.04 \pm 0.13$ & $0.85 \pm 0.08$ & $1.02 \pm 0.10$ & $0.98 \pm 0.16$ \\
Plasma glucose $(\mathrm{mg} / \mathrm{dl})$ & $149 \pm 4$ & $147 \pm 8$ & $145 \pm 6$ & $138 \pm 7$ \\
Plasma free fatty acids $(\mathrm{mM})$ & $0.36 \pm 0.02$ & $0.45 \pm 0.06$ & $0.40 \pm 0.02$ & $0.34 \pm 0.02$ \\
\hline
\end{tabular}

Ten-week-old male mice were fed a chow diet prior to study. Each mouse was treated with 4 intration. Mice had free access to food and were killed at the end of the dark cycle. Each value represents the mean \pm SEM of 6 values. ALevel of statistical significance (2-tailed Student's $t$ test) between the

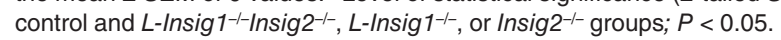
peritoneal injections of plpC ( $300 \mu \mathrm{g} /$ injection), and tissues were obtained 14 days after the final injec-

els of the membrane-bound precursors of SREBP-1 and SREBP-2 (pSREBP-1 and -2) were largely unaffected by deficiency of one or both Insig proteins. A small increase in Scap protein was consistently observed in the livers of mice deficient in Insig1. nSREBP-1 levels were increased by 2 -fold in L-Insig1-/-Insig2 $2^{-/-}$mice compared with those in control mice, while nSREBP-2 levels were unchanged. Hepatic HMGCoA reductase protein levels were slightly elevated in Insig2 ${ }^{-/}$mice and were dramatically elevated in L-Insig $1^{-/-}$Insig2 $2^{-/}$mice.

Figure 2B shows liver cholesterol and triglyceride content in the mice compared in Table 2. The hepatic content of total cholesterol and triglycerides was increased by 4- and 6-fold, respectively,

reduced by approximately $50 \%$ in Insig $2^{+/-}$livers and were undetectable in Insig2-/- livers (Figure $1 \mathrm{H}$ ).

Mice carrying the floxed Insig1 allele were also bred to transgenic mice that express Cre recombinase driven from the adenovirus EIIA promoter (EIIA-Cre). EIIA-Cre mice express Cre in germ cells, which results in germline deletion of the floxed Insig1 allele. Insig $1^{+/-}$ Insig $2^{+/-}$mice were mated to each other in an attempt to produce

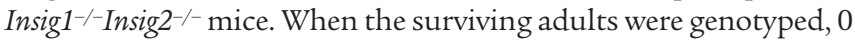

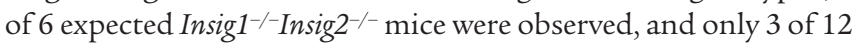
expected Insig1 ${ }^{-/-}$Insig2 $2^{+/}$mice were observed (Table 1).

Further breeding experiments were conducted in which Insig $1^{+/-}$ Insig2 $2^{-1}$ mice were interbred, and pregnant females were killed at 12.5 and 18.5 days post coitum (dpc). At $12.5 \mathrm{dpc}$, the observed

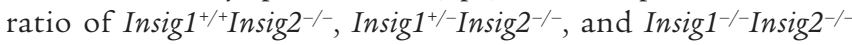
embryos was 46:81:41, which is consistent with the expected 1:2:1

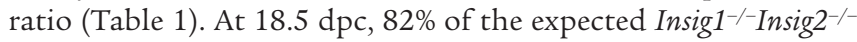
embryos were observed. Further studies into the cause of the neo-

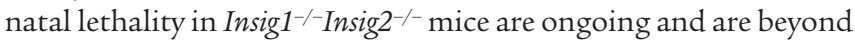
the scope of this work.

In order to study the metabolic effects of total Insig deficiency in adult livers, Insig $1^{\mathrm{f} / \mathrm{f}} \mathrm{MX} 1$-Cre mice were bred with Insig2 $2^{-/-}$mice. Mice of 4 genotypes were produced: $\operatorname{Insig} 1^{\mathrm{f} / \mathrm{f}}$ (designated control), Insig $1^{\mathrm{f} / \mathrm{f}} \mathrm{MX} 1$-Cre (designated $L$-Insig $1^{-/-}$to denote the conditional deficiency of Insig 1 in liver when induced with $\mathrm{pIpC}$ ), Insig $1^{\mathrm{f} / \mathrm{f}}$

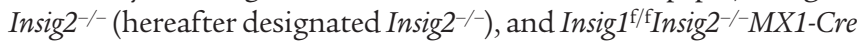
(designated L-Insig1-/-Insig2--). For the studies described in Figures 2-6, all of the mice in each group were injected 4 times with pIpC and then studied between 7 and 14 days after the last injection.

When fed a chow diet ad libitum and sacrificed 14 days after the last $\mathrm{pIpC}$ injection, mice from all genotypes were indistinguishable by external appearance and body weight (Table 2). Plasma cholesterol was slightly elevated, and plasma triglycerides were slightly reduced in $L$-Insig1 $1^{-1-}$ Insig2 $2^{-/-}$mice $(P<0.05,2$-tailed Student's $t$ test). Levels of plasma insulin, glucose, and free fatty acids were similar among the 4 groups.

Figure 2A shows immunoblots of pooled hepatic membrane fractions and nuclear extracts from $\mathrm{pI}$ I C-treated mice of the 4 genotypes compared in Table 2. Mice with single deficiencies of hepatic Insig1 or Insig2 did not compensate by increasing the expression of Insig2 or Insig1, respectively. Levels of hepatic Insig1 protein were dramatically reduced in $L$-Insig $1^{-/-}$Insig2 $2^{-/}$and L-Insig $1^{-/-}$mice. Hepatic Insig2

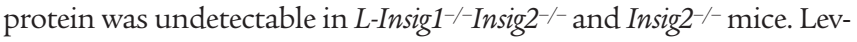

in the L-Insig1 $1^{-/-}$Insig2 $2^{-/-}$mice compared with the hepatic content in control mice on the same diet. In the double-knockout livers, the free cholesterol content rose by 1.4-fold, and the cholesteryl ester content rose by 15 -fold (data not shown). Hepatic lipid levels were normal in mice of the other genotypes. These data indicate that loss of both Insigs is necessary in order to perturb lipid metabolism grossly in mouse liver. For this reason, in all subsequent studies we used $L$-Insig1 $1^{-/}$Insig2 $2^{-/-}$mice.

Table 3 shows the relative expression of various mRNAs in livers from $L$-Insig $1^{-/}$Insig2 $2^{-/}$mice studied in 3 different experiments. The values in control mice for each experiment were assigned as 1 . The mean value for Insig 1 mRNA was reduced by 95\% compared with that of control mice, which reflects the direct action of the Cre recombinase. The Insig2 gene has 2 promoter/enhancer regions that give rise to 2 transcripts, denoted Insig2a and Insig2b (24). The expression of both transcripts was undetectable in L-Insig1-/Insig2 $2^{--}$livers. The mean mRNA values for SREBP-1a, SREBP-2, and Scap were unaffected by Insig deficiency whereas a small increase in SREBP-1c expression (mean of 1.8-fold) was observed. The mRNAs of 5 SREBP target genes involved in fatty acid synthesis were increased by 2.6- to 7.7-fold, consistent with the increase in nSREBP-1 in L-Insig1 $1^{-/}$Insig2 $2^{-/}$livers (see Figure 2A). mRNAs of 4 SREBP targets involved in cholesterol synthesis were generally the same as those in the control mice except for a 2-fold increase in HMG-CoA reductase mRNA. When considered in light of the large increase in the cholesterol content of the Insig-deficient livers, these 4 mRNAs were all inappropriately elevated (see below). mRNAs for ABCG5, ABCG8, and lipoprotein lipase - 3 genes known to be stimulated by LXR $\alpha$ and $\operatorname{LXR} \beta(27)$ - were increased in L-Insig1 $1^{-1}$ Insig2 $2^{-/-}$livers by 3.0- to 5.3-fold. We attribute their increase to the activation of LXRs by the sterols (27) that accumulate in L-Insig1-/-Insig2-/- livers. The mRNA for LXR $\alpha$ itself was unaltered.

Figure $3 \mathrm{~A}$ shows the gross appearance of the livers of control and L-Insig1 $1^{-/}$Insig2 $2^{-/-}$female mice fed a chow diet ad libitum 12 days after injection with pIpC. The liver of the L-Insig1 $1^{-/}$Insig $2^{-/-}$mouse is pale, owing to the accumulation of lipids. The livers from mice of the other 3 genotypes were normal in appearance (data not shown). When liver sections were stained with oil red $\mathrm{O}$, a fat-specific dye, the increase in lipids in the L-Insig1 $1^{-/-}$Insig2 $2^{-/}$mice was dramatic (Figure 3B).

In cultured cells, the reduction of Insig expression creates a relative resistance to the effects of sterols in blocking SREBP processing (14) and accelerating HMG-CoA reductase degradation (21). 
Table 3

mRNAs in liver of $L-$ Insig 1--/nsig2--- mice as compared with values in control mice

\begin{tabular}{|c|c|c|c|c|}
\hline \multirow{2}{*}{$\begin{array}{l}\text { mRNA } \\
\text { Insigs }\end{array}$} & \multicolumn{4}{|c|}{$\begin{array}{l}\text { Relative amount of mRNAs in livers } \\
\text { of } L-\text { Insig1-/-Insig2-- mice }\end{array}$} \\
\hline & Exp. $1^{A}$ & Exp. $2^{B}$ & Exp. $3^{c}$ & Mean \\
\hline Insig1 & 0.05 & 0.09 & 0.00 & 0.05 \\
\hline Insig2a & 0.00 & 0.00 & 0.00 & 0.00 \\
\hline Insig2b & 0.00 & 0.00 & 0.00 & 0.00 \\
\hline \multicolumn{5}{|l|}{ SREBP pathway } \\
\hline SREBP-1a & 1.1 & 1.5 & 1.3 & 1.3 \\
\hline SREBP-1C & 1.1 & 1.8 & 2.5 & 1.8 \\
\hline SREBP-2 & 1.0 & 1.2 & 1.0 & 1.1 \\
\hline Scap & 1.2 & 1.3 & 1.4 & 1.3 \\
\hline \multicolumn{5}{|l|}{ Fatty acid synthesis } \\
\hline ATP citrate lyase & 1.8 & 1.9 & 4.2 & 2.6 \\
\hline Acetyl-CoA carboxylase & 1.9 & 1.8 & 4.5 & 2.7 \\
\hline Fatty acid synthase & 2.9 & 2.6 & 7.9 & 4.5 \\
\hline SCD-1 & 2.9 & 3.1 & 10.2 & 5.4 \\
\hline $\begin{array}{l}\text { Glucose-6-phosphate } \\
\text { dehydrogenase }\end{array}$ & 4.4 & 2.9 & 15.9 & 7.7 \\
\hline \multicolumn{5}{|c|}{ Cholesterol synthesis and uptake } \\
\hline HMG-CoA synthase & 0.6 & 1.5 & 1.5 & 1.2 \\
\hline HMG-CoA reductase & 1.4 & 2.4 & 2.1 & 2.0 \\
\hline FDP synthase & 0.9 & 1.6 & nd & 1.3 \\
\hline LDL receptor & 0.9 & 1.6 & 1.4 & 1.2 \\
\hline \multicolumn{5}{|l|}{ Others } \\
\hline PEPCK & 0.8 & 0.9 & 0.6 & 0.8 \\
\hline $\mathrm{LXR} \alpha$ & 0.9 & 1.4 & 1.2 & 1.2 \\
\hline ABCG5 & 2.2 & 3.1 & 4.7 & 3.4 \\
\hline ABCG8 & 2.0 & 2.9 & 4.0 & 3.0 \\
\hline Lipoprotein lipase & 3.5 & 3.3 & 9.0 & 5.3 \\
\hline
\end{tabular}

The mice used in these experiments (see below) were fed a chow diet ad libitum prior to the study. For each group, equal amounts of total RNA from the livers of 4 to 6 mice were pooled and subjected to realtime PCR quantification as described in Methods. apoB was used as the invariant control. Values represent the amount of mRNA relative to that in control mice in each experiment, which is arbitrarily defined as 1. nd, not measured. ${ }^{A} 10$-week-old male mice; 14 days after final plpC

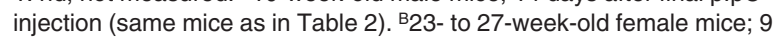
days after final plpC injection. ${ }^{\mathrm{C}} 23$ - to 27 -week-old male mice; 13 days after final plpC injection (same mice as those in Table 5 fed the chow diet containing $0.02 \%$ cholesterol). Exp., experiment.

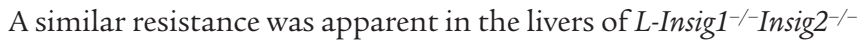
mice. This resistance can be inferred from the observation that nSREBPs were still present and HMG-CoA reductase protein was increased in these livers despite the accumulation of cholesterol to levels that would have reduced these proteins in wild-type mice.

To enable direct comparison of cholesterol regulation in livers of control and L-Insig1-/-Insig2-/- mice, the mice were fed diets containing varying amounts of cholesterol for 2.5 days, after which pSREBPs, nSREBPs, and HMG-CoA reductase were measured by immunoblotting (Figure 4A). Metabolic measurements in these mice are provided in Table 4. When L-Insig1 $1^{-/-}$ Insig2 $2^{-/-}$mice consumed the unsupplemented chow diet, levels of nSREBP-1 were elevated by 2 -fold, and levels of nSREBP- 2 were unaltered. In control mice fed a $2 \%$ cholesterol diet, nSREBP-2 was reduced by $93 \%$ (Figure 4, A and B). This decline was severely blunted in L-Insig1 $1^{-/}$Insig2 $2^{-/}$mice, in whom nSREBP-2 decreased only $17 \%$. When mice were fed high-cholesterol diets, nSREBP-1 decreased slightly in controls and even less in L-Insig1-/-Insig2-/- mice. nSREBP-1 remained elevated in the knockout animals at all levels of dietary cholesterol.

Whereas HMG-CoA reductase protein levels were markedly reduced in control mice fed the $0.2 \%$ and $2.0 \%$ cholesterol diets,

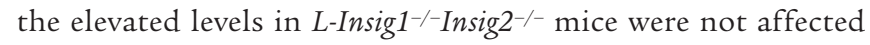
(Figure 4A). Insig1 and Insig2 protein levels were unaffected by cholesterol feeding in control mice and were undetectable in the knockout animals (Figure 4A). Hepatic cholesterol content was markedly elevated in the knockout mice, and it did not increase further with cholesterol feeding (Figure 4C). Hepatic cholesterol increased in the control mice, but it did not reach the high levels seen in the knockout animals.

To confirm that the elevated levels of HMG-CoA reductase protein in the L-Insig1-/-Insig2-/- livers were associated with increases in HMG-CoA reductase activity, we assayed the enzyme activity in liver homogenates. Inasmuch as most HMG-CoA reductase molecules are phosphorylated and inactive $(28,29)$, we homogenized the livers in 2 different buffers. One of these contained sodium fluoride, which stops dephosphorylation during homogenization and is therefore believed to reveal true endogenous HMG-CoA reductase activity. The other contained sodium chloride, which permits dephosphorylation and therefore represents the maximal activity from the enzyme (28). In control mice, cholesterol feeding markedly reduced HMG-CoA reductase activity regardless of the

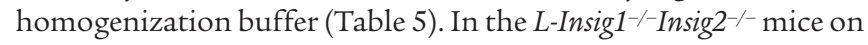
a chow diet, reductase activity was markedly elevated, and it failed to decline after cholesterol feeding. The relative results were the same when the livers were homogenized in fluoride or chloride.

Relevant hepatic mRNAs were quantified by real-time PCR in the livers of mice fed low-cholesterol chow $(0.02 \%)$ or the highcholesterol (2.0\%) diet (Figure 5). Liver expresses 2 major isoforms
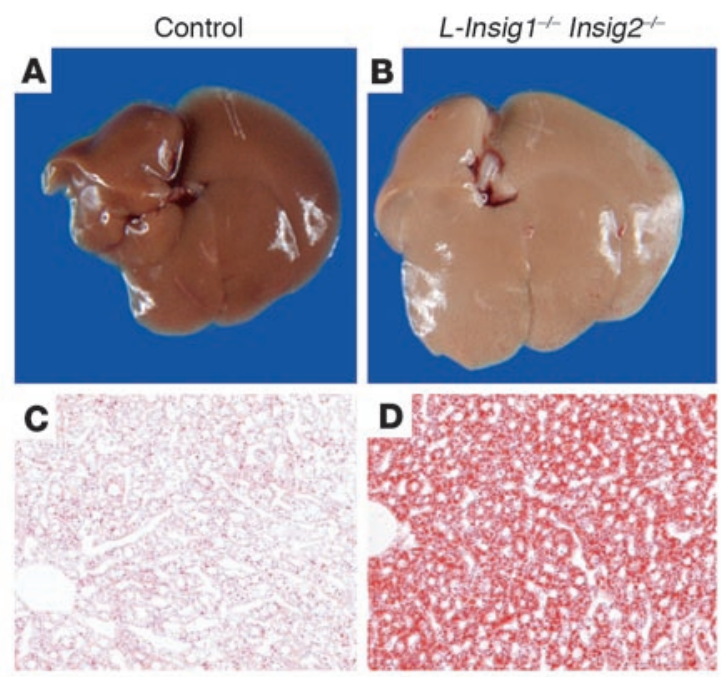

\section{Figure 3}

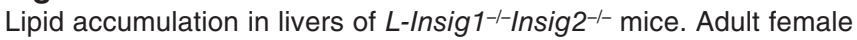
mice were treated with 4 intraperitoneal injections of plpC $(300 \mu \mathrm{g} /$ injection), and the livers were removed either 12 days (A and $\mathbf{B})$ or 7 days $(\mathbf{C}$ and $\mathbf{D})$ after the final injection. (A and $\mathbf{B})$ Photographs of livers

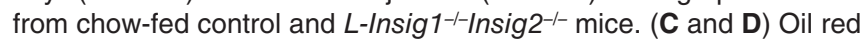
$\mathrm{O}-$ stained histologic sections of the livers from chow-fed control (left) and $L-$ Insig $1^{-/-}$Insig2 $2^{-/}$mice. Mice were perfused through the heart with HBSS and then with $10 \%(\mathrm{v} / \mathrm{v})$ formalin in PBS; frozen sections of livers were stained with oil red $O$. Magnification, $\times 20$. 
Table 4

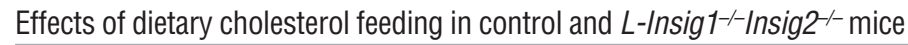

\begin{tabular}{|c|c|c|c|c|c|c|}
\hline \multirow[b]{2}{*}{ Dietary cholesterol (\%) } & \multicolumn{3}{|c|}{ Control } & \multicolumn{3}{|c|}{ L-Insig1-/-Insig2-/- } \\
\hline & $0.02 \%$ & $0.2 \%$ & $2.0 \%$ & $0.02 \%$ & $0.2 \%$ & $2.0 \%$ \\
\hline$n$ & 6 & 6 & 6 & $4^{\mathrm{A}}$ & 6 & 6 \\
\hline Body weight $(\mathrm{g})$ & $24.8 \pm 1.1$ & $24.7 \pm 0.4$ & $25.2 \pm 0.4$ & $25.7 \pm 0.8$ & $25.8 \pm 0.9$ & $25.4 \pm 1.1$ \\
\hline Liver weight $(\mathrm{g})$ & $1.25 \pm 0.04$ & $1.26 \pm 0.02$ & $1.35 \pm 0.06$ & $1.82 \pm 0.07^{B}$ & $1.72 \pm 0.12^{\mathrm{C}}$ & $1.93 \pm 0.15^{c}$ \\
\hline Liver cholesterol content $(\mathrm{mg} / \mathrm{g})$ & $3.2 \pm 0.2$ & $4.3 \pm 0.4$ & $11.3 \pm 0.6$ & $22.4 \pm 3.1^{B}$ & $25.4 \pm 2.5^{B}$ & $26.0 \pm 1.5^{B}$ \\
\hline Liver triglyceride content $(\mathrm{mg} / \mathrm{g})$ & $15.5 \pm 3.0$ & $22.8 \pm 6.9$ & $28.8 \pm 3.8$ & $75.5 \pm 11.7^{\mathrm{B}}$ & $84.2 \pm 9.1^{B}$ & $106.3 \pm 5.0^{B}$ \\
\hline Plasma cholesterol (mg/dl) & $85 \pm 11$ & $91 \pm 3$ & $91 \pm 12$ & $102 \pm 4$ & $95 \pm 9$ & $113 \pm 12$ \\
\hline Plasma triglycerides (mg/dl) & $64 \pm 10$ & $46 \pm 6$ & $39 \pm 5$ & $41 \pm 9$ & $36 \pm 4$ & $34 \pm 5$ \\
\hline Plasma insulin (ng/ml) & $0.46 \pm 0.18$ & $0.53 \pm 0.11$ & $0.56 \pm 0.19$ & $0.97 \pm 0.16$ & $0.63 \pm 0.21$ & $0.59 \pm 0.14$ \\
\hline Plasma glucose (mg/dl) & $100 \pm 5$ & $108 \pm 8$ & $112 \pm 7$ & $126 \pm 11$ & $108 \pm 6$ & $123 \pm 6$ \\
\hline Plasma free fatty acids (mM) & $0.47 \pm 0.06$ & $0.35 \pm 0.05$ & $0.32 \pm 0.04$ & $0.35 \pm 0.04$ & $0.45 \pm 0.07$ & $0.44 \pm 0.09$ \\
\hline
\end{tabular}

Female mice (20-24 weeks of age) were fed ad libitum a chow diet containing the indicated amount of cholesterol for 2.5 days prior to study. Each mouse was treated with 4 intraperitoneal injections of plpC ( $300 \mu \mathrm{g} /$ injection), and tissues were obtained 11 days after the final injection. Each value represents the mean \pm SEM of 4 or 6 values. ${ }^{A}$ Of the 6 mice in this group, 2 did not respond to treatment with plpC as assessed by quantitative real-time PCR. The

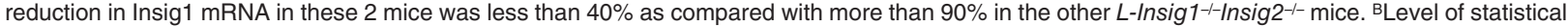
significance (2-tailed Student's $t$ test) between the control and $L$-Insig $1^{-/-}$Insig2 ${ }^{-/-}$groups; $P<0.001$. ${ }^{C} P<0.01$.

of SREBPs: SREBP-1c and SREBP-2 (30). Although their functions overlap, SREBP-1c preferentially activates the genes involved in fatty acid and triglyceride synthesis while SREBP-2 preferentially activates the genes required for cholesterol synthesis (31). mRNAs for both SREBP-1c and -2 are enhanced by nSREBPs themselves in a feed-forward activation loop and, in addition, SREBP-1c mRNA is induced by insulin and by agonists of LXRs (32). In control mice, SREBP-1c mRNA was induced 2-fold by high-cholesterol feeding, which we attribute to the activation of LXRs by oxysterols gen- erated from dietary sterols (33). In the sterol-overloaded livers of L-Insig1 $1^{-/}$Insig2 $2^{-/-}$mice, SREBP-1c mRNA was elevated by 2 -fold and did not rise further after cholesterol feeding. SREBP-2 mRNA was suppressed by $46 \%$ in control mice fed the high-cholesterol diet; this decline was blunted in L-Insig1 $1^{-/}$Insig2 ${ }^{-/-}$mice. The decline of SREBP-2 mRNA in control mice is likely due to the loss of feedforward activation as SREBP processing is reduced by the increase in hepatic cholesterol. In the double-knockout mice, the loss of Insigs prevents cholesterol from blocking SREBP processing, and

\section{Figure 4}

Markedly elevated levels of nSREBPs and HMGCoA reductase in the livers of Insig-deficient mice fed high-cholesterol diets. The mice used for this figure are the same as those compared in Table 4. Each mouse was treated with 4 intraperitoneal injections of plpC (300 $\mu \mathrm{g} /$ injection); 8.5 day after the final injection, mice were fed ad libitum a chow diet containing the indicated amount of cholesterol for 2.5 days prior to study. (A) Immunoblot analysis of SREBP-1 and SREBP-2 from livers of control

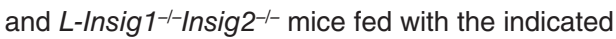
amount of cholesterol. Livers (4 or 6 per group) were separately pooled, and $45-\mu \mathrm{g}$ aliquots of the membrane and nuclear extract fractions were subjected to SDS-PAGE and immunoblot analysis. Nonspecific bands are denoted by the asterisk. Arrows indicate the position of migration on SDS gels of monomeric HMG-CoA reductase (97 kDa). Immunoblots of CREB and transferrin receptor were used as loading controls for the nuclear extract and membrane fractions, respectively. (B) The gels of nuclear extract fractions (nuclear) shown in $\mathbf{A}$ were scanned and quantified by densitometry. The intensities of cleaved nSREBP-1 and nSREBP-2 in lane 1 (control mice fed with $0.02 \%$ cholesterol) were arbitrarily set at $100 \%$. (C) Hepatic cholesterol content of control and Insig-deficient mice. Each value represents the mean \pm SEM of data from 4 or 6 mice.
A
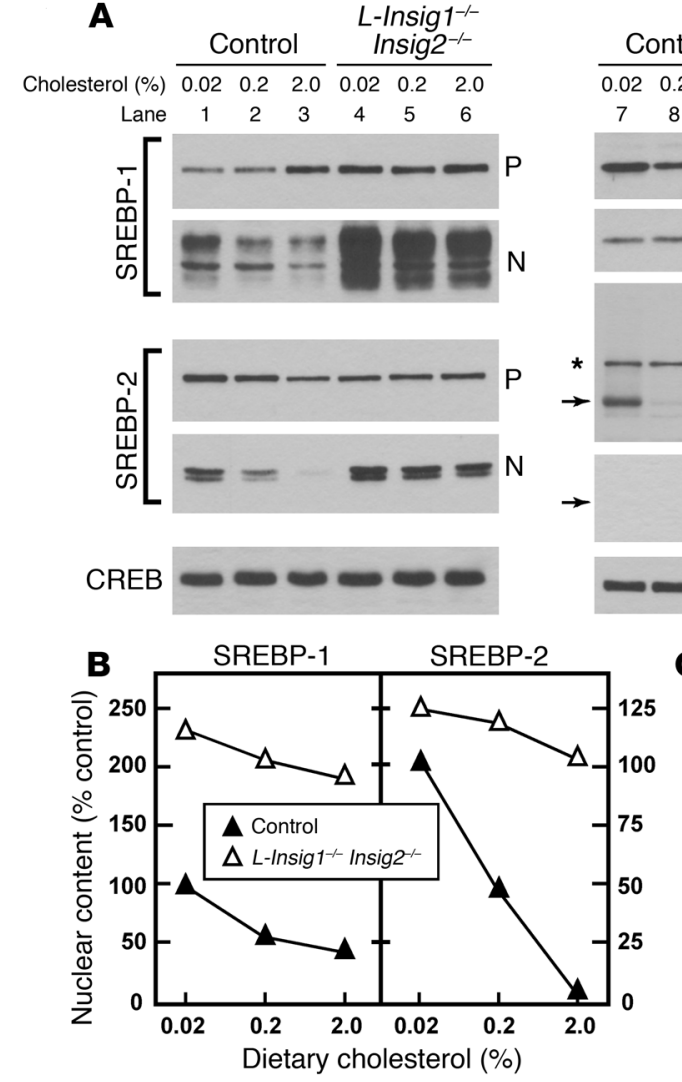

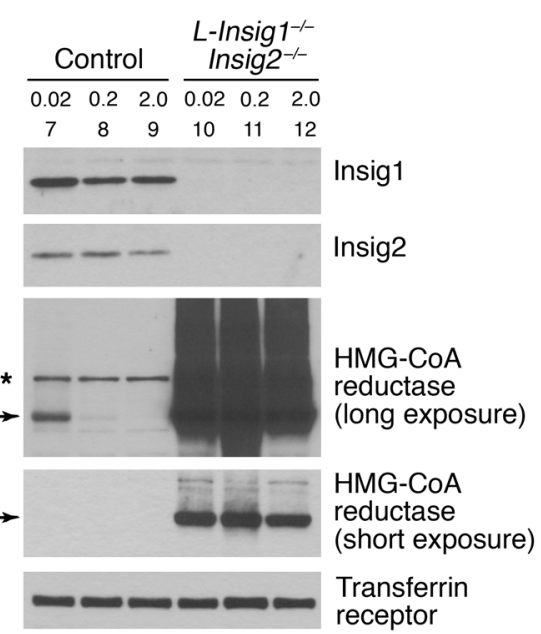

C

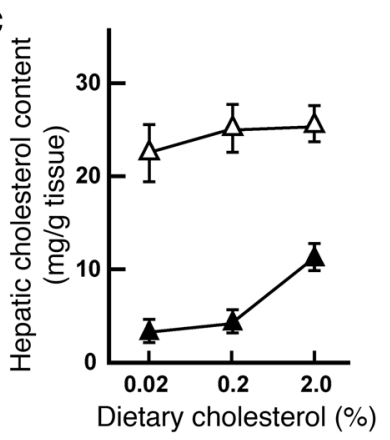


Table 5

HMG-CoA reductase activity in livers of cholesterol-fed mice

\begin{tabular}{|c|c|c|c|}
\hline \multirow[b]{2}{*}{ Genotype } & \multirow{2}{*}{$\begin{array}{l}\text { Cholesterol } \\
\text { in diet }\end{array}$} & \multicolumn{2}{|c|}{$\begin{array}{l}\text { HMG-COA reductase activity } \\
(\mathrm{pmol} / \mathrm{min} / \mathrm{mg} \text { protein) }\end{array}$} \\
\hline & & $+\mathrm{NaF}$ & $+\mathrm{NaCl}$ \\
\hline Control & $\begin{array}{l}0.02 \% \\
1.5 \%\end{array}$ & $\begin{array}{c}161 \pm 10 \\
39 \pm 5\end{array}$ & $\begin{aligned} 998 & \pm 19{ }^{A} \\
59 & \pm 13\end{aligned}$ \\
\hline L-Insig 1-1-Insig2--- & $\begin{array}{c}0.02 \% \\
1.5 \%\end{array}$ & $\begin{array}{l}2169 \pm 120 \\
2436 \pm 45\end{array}$ & $\begin{array}{l}5423 \pm 203 \\
5024 \pm 157\end{array}$ \\
\hline
\end{tabular}

Male mice (23-27 weeks of age; $n=5$ ) were fed ad libitum a chow diet containing the indicated amount of cholesterol for 2.5 days prior to study. Each mouse was treated with 4 intraperitoneal injections of plpC (300 $\mu \mathrm{g} /$ injection), and tissues were obtained 13 days after the final injection. Livers from 5 mice in each group were individually homogenized in buffer containing either $\mathrm{NaF}$ or $\mathrm{NaCl}$, after which the homogenates were pooled and the resulting microsomes were assayed for HMG-CoA reductase activity in the presence of either $\mathrm{NaF}$ or $\mathrm{NaCl}$ as indicated. ${ }^{A}$ Mean \pm SEM of triplicate assays.

thus the SREBP-2 mRNA does not decline. Consistent with this hypothesis, SREBP-2 target mRNAs for genes involved in cholesterol synthesis (HMG-CoA reductase, HMG-CoA synthase, farnesyl diphosphate [FDP] synthase, and squalene synthase) declined by more than $75 \%$ when control mice were fed the high-cholesterol diet. Levels of these mRNAs were elevated by 1.7- to 2.6-fold in L-Insig $1^{-1}$-Insig $2^{-/-}$mice. They declined partially when the animals were fed the high-cholesterol diet, but remained greater than or equal to levels in control mice fed the low-cholesterol diet.

Levels of mRNAs for genes involved in fatty acid and triglyceride synthesis were elevated 2.5- to 5.5 -fold in the L-Insig1-/-Insig2-/mice. These mRNA levels declined only slightly with cholesterol feeding in both the control and the knockout animals (Figure 5). mRNAs for the LXR-responsive genes ABCG5 and ABCG8 were induced by high-cholesterol feeding in control mice. These mRNAs were elevated in L-Insig $1^{-/-}$Insig2 $2^{--}$mice, and they did not increase with cholesterol feeding, which is consistent with the hypothesis that hepatic LXRs were already activated by sterols in the livers of

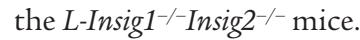

To test the effect of Insig deficiency on hepatic lipid synthesis, male control and L-Insig $1^{-/}$-Insig $2^{-/}$mice were fed diets containing $0.02 \%$ (low) or $1.5 \%$ (high) cholesterol for 2.5 days, after which in vivo lipid synthesis was determined by measurement of the incorporation of intraperitoneally injected ${ }^{3} \mathrm{H}$-labeled water into digitonin-precipitable sterols and fatty acids (Figure 6). High-cholesterol feeding reduced hepatic sterol synthesis by $93 \%$ in control mice. Hepatic sterol synthesis in L-Insig1-/Insig2-/- mice was elevated by 5 -fold, and it did not decline with the high-cholesterol diet. Hepatic fatty acid synthesis was 3-fold higher in L-Insig ${ }^{-/- \text {Insig2 }}{ }^{-/-}$mice fed the low-cholesterol diet compared with that in control mice. The synthesis of sterols and fatty acids in brain, a tissue with a very low level of interferon-induced $M X 1$-Cre recombination (26), was normal in L-Insig $1^{-/}$-Insig2 $2^{-/}$mice.

\section{Discussion}

The current studies in this paper define Insigs as essential components of the cholesterol feedback response that Schoenheimer discovered in living mice more than 70 years ago (1). Considered together with previous experiments in mouse liver, our data indicate that the entire pathway for SREBP processing functions in this organ and that this pathway is responsible for the synthesis of cholesterol as well as the feedback suppression of synthesis when cholesterol is consumed in the diet.

The first indication that SREBPs control cholesterol synthesis in liver came from the production of transgenic mice expressing truncated versions of SREBPs that lack a membrane-spanning segment and enter the nucleus without a requirement for processing (32). Overexpression of nSREBP-1a or nSREBP-2 markedly increased cholesterol synthesis in liver and led to massive intrahepatic accumulation of cholesterol $(34,35)$. Overexpression of nSREBP- $1 \mathrm{c}$ was much less potent in this regard (36). To show that endogenous levels of SREBPs are sufficient for cholesterol overproduction, transgenic mice were created that express a mutant form of Scap that escorts SREBPs normally, but cannot bind to Insigs

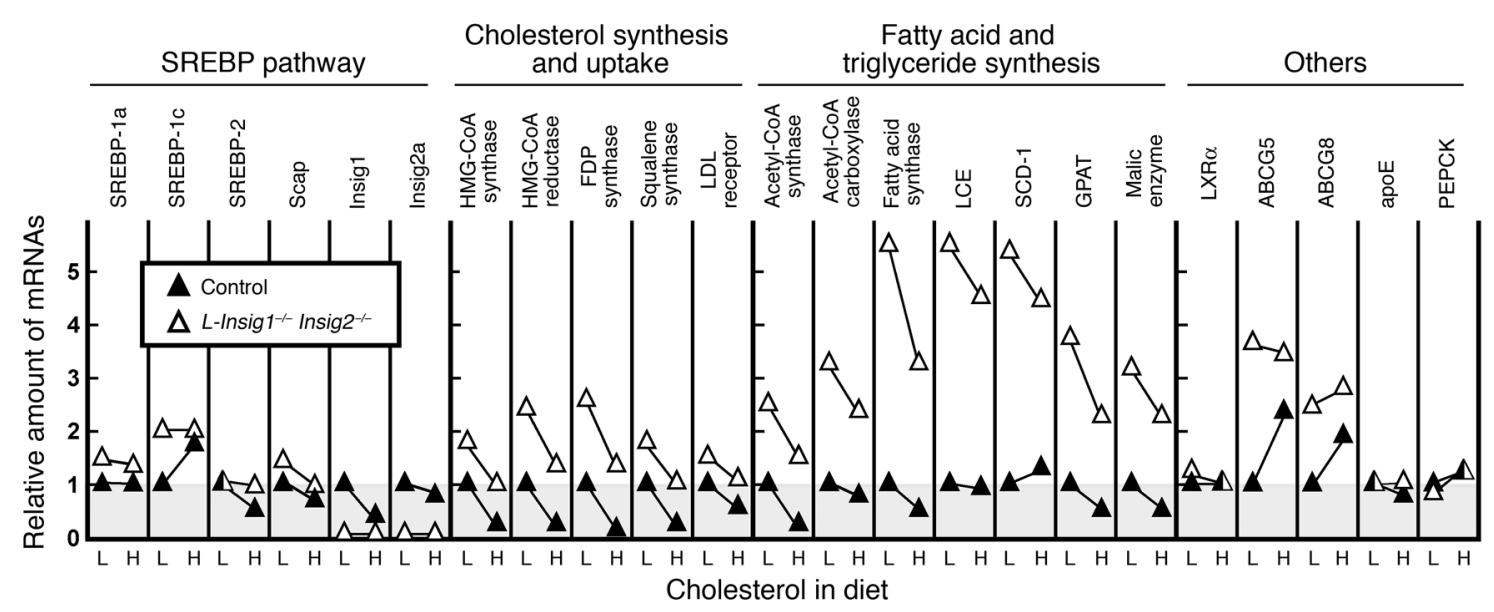

Figure 5

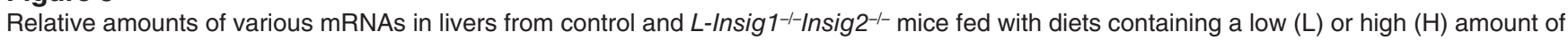
cholesterol $(0.02 \%$ or $2.0 \%$ cholesterol, respectively). The mice used here are the same as those used for Figure 4 and Table 4 . Total RNA from livers of mice was pooled and subjected to real-time PCR quantification as described in Methods. Each value represents the amount of mRNA relative to that in the control mice fed with a chow diet $(0.02 \%$ cholesterol), which is arbitrarily defined as 1 . LCE, long-chain fatty acyl-CoA elongase; SCD-1, stearoyl-CoA desaturase-1; GPAT, glycerol-3-phosphate acyltransferase; PEPCK, phosphoenolpyruvate carboxykinase. 


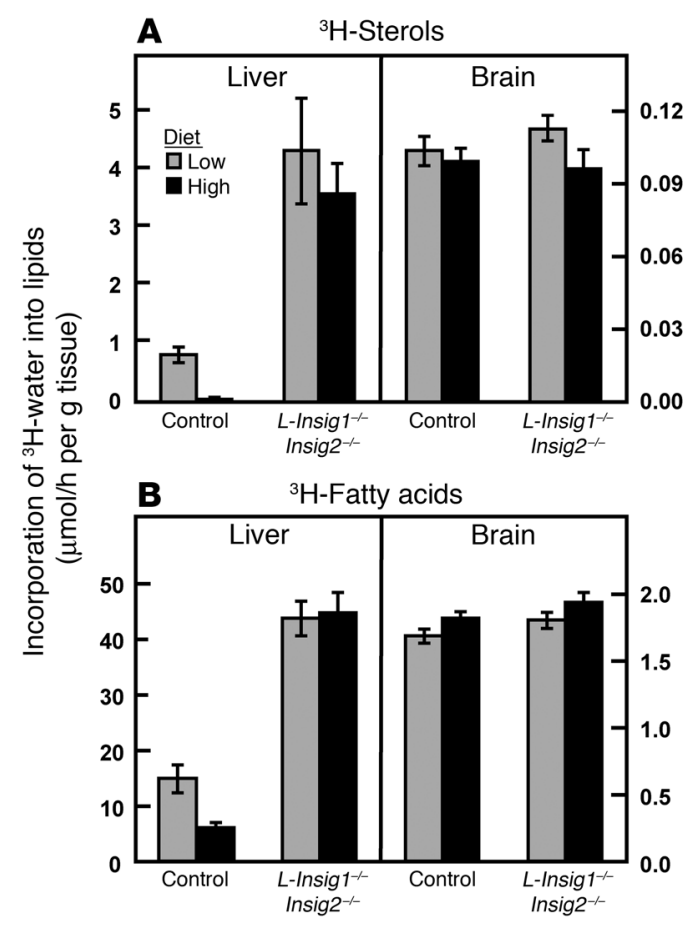

Figure 6

In vivo synthesis rates of sterols (A) and fatty acids (B) in livers and

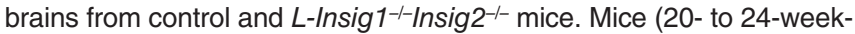
old males; 5 or 6 per group) were treated with 4 intraperitoneal injections of plpC (300 $\mu \mathrm{g} /$ injection). Five and a half days after the final injection, mice were fed ad libitum a chow diet containing $0.02 \%$ (low) or $1.5 \%$ (high) cholesterol for 2.5 days prior to sacrifice, at which time the mice were injected intraperitoneally with ${ }^{3} \mathrm{H}$-labeled water $(50-\mathrm{mCi}$ in $0.20 \mathrm{ml}$ of isotonic saline). One hour later the tissues were removed for measurement of ${ }^{3} \mathrm{H}$-labeled fatty acids and digitonin-precipitable sterols. Each bar represents the mean \pm SEM of the values from 5 or 6 mice.

$(10,37)$. The livers of these mice also overproduced cholesterol and were resistant to feedback inhibition by dietary cholesterol. Cre-mediated elimination of Scap in the liver (38) or of one of the SREBP-processing proteases (39) reduced the amount of nSREBPs and led to a severe reduction in cholesterol synthesis, indicating that nSREBPs are required for transcription of the genes encoding enzymes of the cholesterol biosynthetic pathway in liver.

Although elimination of Insig1 alone had a minor effect on nSREBPs and its target mRNAs, full derepression of cholesterol synthesis required the elimination of both Insig1 and Insig2. These data indicate that Insig2 plays an important role in liver. Although Insigs are required in sterol-mediated feedback inhibition of the processing of SREBP-1 and SREBP-2, the 2 SREBPs show a differential sensitivity to cholesterol. As shown in Figure 4, A and B, cholesterol feeding of wild-type mice nearly eliminated nSREBP-2, but it reduced nSREBP-1 by only about $50 \%$. We know that both of these responses were mediated by Insigs since they did not occur

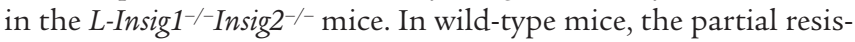
tance of SREBP-1 may be due in part to an increase in pSREBP-1c, owing to an increase in SREBP-1c mRNA (Figure 5), which is produced by sterol-mediated activation of LXRs (31). However, it seems unlikely that the increase in PSREBP-1c is solely responsible for this resistance. Inhibition of SREBP processing is mediated by the binding of the Scap-SREBP complex to Insigs. The possibility therefore exists that the Scap-SREBP-1 complex in liver may have a lower affinity for Insigs than does the Scap-SREBP-2 complex. These possibilities and others are open to study now that the role of Insigs in cholesterol feedback has been demonstrated in liver.

\section{Methods}

Materials and general methods. Blood was drawn from the retro-orbital sinus; plasma was separated immediately and stored at $-70^{\circ} \mathrm{C}$. Plasma glucose was measured with a Glucometer (994-90902; Bayer). Concentrations of plasma and liver cholesterol and triglycerides and of plasma free fatty acids and insulin were measured as described (25). PIpC was obtained from Sigma-Aldrich (P1530) and Amersham Biosciences (27-4729-01).

Generation of Insig knockout mice. The Insig1 gene was conditionally disrupted by the insertion of a loxP, frt-flanked pgkneopA cassette (40) $2.3-\mathrm{kb}$ upstream of the initiator ATG codon of exon 1 of Insig1 and the insertion of a downstream loxP site within intron 1. Regions of homology were generated by PCR using SM-1 ES cell genomic DNA as a template and were then inserted into a targeting vector, pJB1 (kindly provided by Joachim Herz, University of Texas Southwestern Medical Center). Cre-mediated recombination removed exon 1, which encodes amino acids 1-119.

The Insig2 gene was disrupted by replacement of exons 2 and 3 with a polIIsneopA cassette (41) to remove sequences that encode amino acids 1-123. Regions of homology were generated by PCR using SM-1 ES cell genomic DNA as a template and inserted into the targeting vector pGEM3Zf $(+)$ containing a polIIsneopA cassette. The integrity of all constructs was confirmed by restriction analysis and DNA sequencing.

SM-1 ES cells, derived from 129S6/SvEv blastocysts, were cultured on leukemia inhibitory factor-producing STO feeder cells and transfected with linearized targeting vectors as described previously $(41,42)$. ES cell clones that had undergone homologous recombination as determined by PCR and Southern blotting were isolated and injected into C57BL/6J blastocysts. Chimeric males with more than $50 \%$ agouti coat color were crossed to $\mathrm{C} 57 \mathrm{BL} / 6 \mathrm{NCrl}$ females. From single ES cell lines, 7 chimeric males produced offspring that carried a single copy of the targeted Insig1 allele (referred to as Insig $1^{+/ /}$), and 6 chimeric males produced offspring that carried a single copy of the disrupted Insig2 allele (referred to as Insig2 ${ }^{+/}$).

To generate mice with inducible disruption of the floxed Insig1 allele, Insig $1^{+/ f}$ mice were bred to $M X 1$-Cre transgenic mice to generate Insig $1^{\mathrm{f} / \mathrm{f}}$ MX1-Cre (L-Insig 1-/-) mice (43). Littermates of L-Insig $1^{-/-}$mice lacking the Cre transgene were used as control mice. L-Insig $1^{-/-}$mice were bred

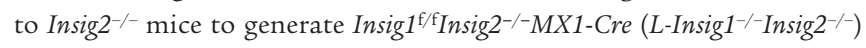
mice. Littermates of $L$-Insig $1^{-/}$Insig $2^{-/-}$mice lacking the Cre transgene are referred to as Insig2 $2^{--}$mice. Disruption of Insig1 in the liver was induced by intraperitoneal injection of $\mathrm{pIpC}$, which induces interferon, which in turn induces the Cre recombinase driven by the $M X 1$ promoter (26). For the studies described here, each mouse (control, L-Insig1 $1^{-/}$, Insig2 $2^{-/}$, or L-Insig $1^{-/}$Insig2 $2^{--}$) received 4 intraperitoneal injections of $300 \mu \mathrm{lof}$ a $1 \mathrm{mg} /$ $\mathrm{ml}$ solution of $\mathrm{PI} \mathrm{PC}$ in water or PBS administered every 48 hours. Mice were analyzed between 7 and 14 days after the final PIpC injection. Disruption of the floxed Insig1 allele in all mice was confirmed by either Southern blot analysis of NcoI-digested genomic DNA or by measurement of Insig1 mRNA by quantitative real-time PCR of total RNA from livers of PIpCtreated mice. L-Insig1 $1^{-/}$Insig2 $2^{-/-}$mice demonstrating low levels of disruption of the floxed Insig1 allele were excluded from further analysis (see legend to Table 4). During the course of these studies, we observed batch-to-batch variation in the potency of $\mathrm{PIpC}$, and, in general, higher disruption was seen when the $\mathrm{PI}$ I C was administered in PBS rather than water.

To generate mice with disruption of the floxed Insig1 allele in the whole animal, Insig $1^{+/ \mathrm{f}}$ mice were bred to EIIa-Cre transgenic mice (strain $\mathrm{FVB} / \mathrm{N} /$ $\operatorname{Tg}$ (EIIa-cre)C5379Lmgd/J, 003314; Jackson Laboratory). Cre recombinase 
driven by the adenovirus EIIA promoter is active in the tissues of the developing animal, including the germ cells (44). Mice carrying a single copy of the disrupted Insig1 allele in all tissues (referred to as Insig $1^{+/-}$mice) were bred to Insig2 $2^{+/-}$mice. Genotypes of the resultant offspring are described in Table 1.

To genotype knockout animals, genomic DNA was prepared from adult tail or embryonic tissue using a direct lysis kit from Viagen Biotech (102-T) and used for PCR with the following primers: Insig1: $5^{\prime}$ primer-1, 5'CTCAAGAGGCAGTTGCCAGGGGACAGACTT-3'; 5' primer-2, 5'-GCCACATAGGCTTCTGCATAGAAACACACT-3'; and 3' primer (common), 5'-CACTTGACAAATGGTTATCAACGCTGTACA-3'. Insig1 genotyping yielded PCR products of 296, 393, and $567 \mathrm{bp}$ from the wild-type, floxed, and disrupted alleles, respectively. Insig2: $5^{\prime}$ primer-1, 5'-CCTGCATTGACAGGCATCTAGGAGAACCTC-3'; 5' primer-2, 5'-GATTGGGAAGACAATAGCAGGCATGC-3'; and 3' primer (common), 5'-AGGGTACTTCTTGGTGCTGACTATAACCAA-3'. Insig2 genotyping yielded PCR products of 477 and $357 \mathrm{bp}$ from the wild-type and disrupted alleles, respectively.

All mice were housed in colony cages with 12-hour light/12-hour dark cycles and fed Teklad Mouse/Rat Diet 7002 from Harlan Teklad Global Diets. Unless otherwise stated, mice were fed a chow diet ad libitum, and tissues were collected at the end of the dark phase. All animal experiments were performed with the approval of the Institutional Animal Care and Research Advisory Committee at University of Texas Southwestern Medical Center at Dallas.

Diet studies. For the cholesterol-feeding studies, mice were fed for 2.5 days with a chow diet $(0.02 \%$ cholesterol) or chow diet containing cholesterol at a final concentration $(\mathrm{w} / \mathrm{w})$ of $0.2 \%, 1.5 \%$, or $2.0 \%$. High-cholesterol diets were prepared by grinding solid cholesterol (101380; MP Biomedicals) directly into the powdered chow diet (Mouse/Rat Diet 7001; Harlan Teklad Global Diets) with a mortar and pestle.

Quantitative real-time PCR and Northern blot analysis. Total RNA was prepared from mouse tissues using an RNA STAT-60 kit (TEL-TEST "B"). Equal amounts of RNA from 4 to 6 mice were pooled and subjected to quantitative real-time PCR as previously described (25). apoB mRNA was used as the invariant control. The primers for real-time PCR have been previously described $(24,39,42)$.

For Northern blot analysis, pooled total RNA was subjected to electrophoresis in a $1 \%$ agarose gel and transferred to Hybond XL membranes (RPN303S; Amersham Biosciences). cDNA probe preparation and hybridization were carried out as previously described (45). The Insig1 probe consisted of the full-length mouse Insig1 open-reading frame (25). Probes for Insig2 and cyclophilin have previously been described $(11,46)$.

Immunoblot analyses of liver nuclear extracts and membrane fractions. To prepare nuclear and membrane fractions for immunoblot analyses, aliquots of frozen liver $(100 \mathrm{mg})$ were homogenized in $1 \mathrm{ml}$ buffer $(20$-mM Trischloride at $\mathrm{pH} 7.4,2-\mathrm{mM} \mathrm{MgCl}_{2}, 0.25-\mathrm{M}$ sucrose, $10-\mathrm{mM}$ sodium EDTA, and $10-\mathrm{mM}$ sodium EGTA) supplemented with protease inhibitor cocktail consisting of 5-mM dithiothreitol, 0.1-mM leupeptin, 1-mM phenylmethylsulfonyl fluoride, $0.5-\mathrm{mM}$ Pefabloc, $5-\mu \mathrm{g} / \mathrm{ml}$ pepstatin A, $25-\mu \mathrm{g} / \mathrm{ml}$ $N$-acetyl-leu-leu-norleucinal, $10-\mu \mathrm{g} / \mathrm{ml}$ aprotinin, and the equivalent of 0.1 tablet of Complete Mini Inhibitor Cocktail (11836170001; Roche Diagnostics Corp.). The liver homogenate was centrifuged at $1000 \mathrm{~g}$ for $5 \mathrm{~min}$ at $4{ }^{\circ} \mathrm{C}$. The supernatant was removed and used to prepare a membrane fraction as previously described (25). To prepare nuclear extracts, the pellet was washed in $2 \mathrm{ml}$ of homogenization buffer and collected by centrifugation at $1000 \mathrm{~g}$ for 5 minutes at $4^{\circ} \mathrm{C}$. The nuclear pellet was resuspended in 0.3 $\mathrm{ml}$ of buffer (20-mM HEPES-NaOH at pH7.6, 2.5\% glycerol, 0.42-M NaCl, $1.5-\mathrm{mM} \mathrm{MgCl}_{2}, 1-\mathrm{mM}$ sodium EDTA, 1 -mM sodium EGTA, and the equivalent of 0.03 protease inhibitor tablet). The suspension was rotated at $4^{\circ} \mathrm{C}$ for 1 hour and centrifuged at $1 \times 10^{5} \mathrm{~g}$ for 30 minutes at $4^{\circ} \mathrm{C}$. The supernatant from this spin was designated the nuclear extract. After aliquots of the nuclear extract and membrane fraction were removed for measuring protein concentration with the BCA Kit (Pierce Biotechnology Inc.), the remainder of each sample was mixed with $4 \times$ SDS loading buffer $(12 \%(\mathrm{w} / \mathrm{v})$ SDS, $0.02 \%$ bromophenol blue, $30 \%$ glycerol, $0.15-\mathrm{M}$ Tris-chloride at $\mathrm{pH}$ 6.8 , and $6 \% \beta$-mercaptoethanol). Equal amounts of protein from the livers of 4 to 6 mice were then pooled, and an aliquot of the pooled sample (45 $\mu \mathrm{g})$ was subjected to SDS-PAGE and immunoblot analysis $(25,47)$.

Rabbit polyclonal antibodies that detect mouse SREBP-1, SREBP-2, Insig1, Insig2, HMG-CoA reductase, and Scap were described previously $(25,29,48,49)$. These antibodies were diluted in $5 \%$ bovine serum albumin (A7906; Sigma-Aldrich) in PBS-0.05\% Tween-20 (P3563; Sigma-Aldrich) and used at the indicated concentrations: SREBP-1 (IgG fraction, $5-\mu \mathrm{g} /$ $\mathrm{ml}$ ), SREBP-2 (IgG, $2.9-\mu \mathrm{g} / \mathrm{ml})$, Insig1 (1:1000 dilution of serum), Insig2 (1:1000 dilution of serum), HMG-CoA reductase $(\mathrm{IgG}, 3.4-\mu \mathrm{g} / \mathrm{ml})$, and Scap (IgG, 3.5- $\mu \mathrm{g} / \mathrm{ml}$ ). Immunoblots of cAMP-responsive element-binding protein (CREB) and transferrin receptor were used as loading controls for the nuclear extract and membrane fractions, respectively. Anti-CREB (13-6800; Zymed Laboratories Inc.) and antitransferrin receptor antibodies were each used at 0.5- $\mu \mathrm{g} / \mathrm{ml}$ (35-0900; Zymed Laboratories Inc.).

Cholesterol and fatty acid synthesis in vivo. Rates of cholesterol and fatty acid synthesis were measured in control and L-Insig $1^{-1-}$ Insig $2^{{ }^{--}}$mice using ${ }^{3} \mathrm{H}$-labeled water as previously described (34). The mice were fed ad libitum with chow diets containing $0.02 \%$ (low) or $1.5 \%$ (high) cholesterol for 2.5 days prior to study. The rates of cholesterol and fatty acid synthesis were calculated as $\mu$ moles of ${ }^{3} \mathrm{H}$-labeled water incorporated into fatty acids or digitonin-precipitable sterols per hour per gram of tissue.

Assay of HMG-CoA reductase activity. Mice were sacrificed at the end of the dark phase, the livers were immediately removed, and 2 equal pieces of liver $(250 \mathrm{mg} /$ piece $)$ from each mouse were individually homogenized on ice with 10 strokes of a loose Dounce pestle followed by 5 strokes of a tight pestle in $1.5 \mathrm{ml}$ of solution containing 0.3 -M sucrose, $10-\mathrm{mM}$ sodium EDTA at $\mathrm{pH} 7.4,10-\mathrm{mM} \beta$-mercaptoethanol, and either $50-\mathrm{mM}$ $\mathrm{NaF}$ or $50-\mathrm{mM} \mathrm{NaCl}$. Homogenates from 5 mice in each group were then pooled and centrifuged for 15 minutes at $12,000 \mathrm{~g}$ at $4{ }^{\circ} \mathrm{C}$, and the supernatant fraction was again centrifuged for 15 minutes at $12,000 \mathrm{~g}$. The resulting supernatant was centrifuged for 60 minutes at $1 \times 10^{5} \mathrm{~g}$, and the resulting microsomal pellet was frozen at $-80^{\circ} \mathrm{C}$. Before assay of HMG-CoA reductase activity, each pellet was resuspended in $2 \mathrm{ml}$ of assay buffer (20-mM imidazole at $\mathrm{pH}$ 7.4, 5-mM dithiothreitol, and either $50-\mathrm{mM} \mathrm{NaF}$ or $50 \mathrm{mM}-\mathrm{NaCl}$ ), and aliquots were removed for protein quantification and enzyme assay as previously described (50). Each assay was carried out for 30 minutes at $37^{\circ} \mathrm{C}$ in the presence of $87 \mu \mathrm{M}$ DL $\left[3-{ }^{14} \mathrm{C}\right]$ HMG-CoA $(22,051 \mathrm{dpm} / \mathrm{nmol})$. The amount of $\left[{ }^{14} \mathrm{C}\right]$ mevalonate formed was quantified by thin-layer chromatography. Reductase activity is expressed as the picomoles of $\left[{ }^{14} \mathrm{C}\right]$ mevalonate formed per minute per mg of microsomal protein.

Statistics. Statistical analyses were performed using the Fisher exact test (1-tailed) or the Student's $t$ test (2-tailed) as described in Table legends.

\section{Acknowledgments}

We thank Monica Mendoza, Isis DeSoto, Richard Gibson, and Liz Lummus for invaluable help with animal studies; Scott Clark, Emily Brown, Deborah Morgan, and Rachael Salas for excellent technical assistance; and Jeff Cormier for DNA sequencing and help with RT-PCR. This research was supported by grants from the NIH (HL-20948), the Perot Family Foundation, and the Moss Heart Foundation.

Received for publication May 11, 2005, and accepted in revised form May 31, 2005. 
Address correspondence to: Joseph L. Goldstein or Michael S. Brown, Department of Molecular Genetics, University of Texas Southwestern Medical Center, Dallas, Texas 75390-9046,
USA. Phone: (214) 648-2141; Fax: (214) 648-8804; E-mail: joe. goldstein@utsouthwestern.edu (J.L. Goldstein). E-mail: mike. brown@utsouthwestern.edu (M.S. Brown).
1. Schoenheimer, R., and Breusch, F. 1933. Synthesis and destruction of cholesterol in the organism. J. Biol. Chem. 103:439-448.

2. Gould, R.G. 1951. Lipid metabolism and atherosclerosis. Am. J. Med. 11:209-227.

3. Gould, R.G., Taylor, C.B., Hagerman, J.S., Warner, I., and Campbell, D.J. 1953. Cholesterol metabolism. I. Effect of dietary cholesterol on the synthesis of cholesterol in dog tissue in vitro. J. Biol. Chem. 201:519-523.

4. Brown, M.S., and Goldstein, J.L. 1980. Multivalent feedback regulation of HMG CoA reductase, a control mechanism coordinating isoprenoid synthesis and cell growth. J. Lipid Res. 21:505-517.

5. Brown, M.S., and Goldstein, J.L. 1997. The SREBP pathway: regulation of cholesterol metabolism by proteolysis of a membrane-bound transcription factor [review]. Cell. 89:331-340.

6. Nohturfft, A., DeBose-Boyd, R.A., Scheek, S., Goldstein, J.L., and Brown, M.S. 1999. Sterols regulate cycling of SREBP cleavage-activating protein (SCAP) between endoplasmic reticulum and Golgi. Proc. Natl. Acad. Sci. U. S. A. 96:11235-11240.

7. Nohturfft, A., Yabe, D., Goldstein, J.L., Brown, M.S., and Espenshade, P.J. 2000. Regulated step in cholesterol feedback localized to budding of SCAP from ER membranes. Cell. 102:315-323.

8. Espenshade, P.J., Li, W.-P., and Yabe, D. 2002. Sterols block binding of COPII proteins to SCAP, thereby controlling SCAP sorting in ER. Proc. Natl. Acad. Sci. U. S. A. 99:11694-11699.

9. Sun, L.-P., Li, L., Goldstein, J.L., and Brown, M.S. 2005. Insig required for sterol-mediated inhibition of Scap/SREBP binding to COPII proteins in vitro. J. Biol. Chem. 280:26483-26490.

10. Yang, T., et al. 2002. Crucial step in cholesterol homeostasis: sterols promote binding of SCAP to INSIG-1, a membrane protein that facilitates retention of SREBPs in ER. Cell. 110:489-500.

11. Yabe, D., Brown, M.S., and Goldstein, J.L. 2002. Insig-2, a second endoplasmic reticulum protein that binds SCAP and blocks export of sterol regulatory element-binding proteins. Proc. Natl. Acad. Sci. U. S. A. 99:12753-12758.

12. Radhakrishnan, A., Sun, L.-P., Kwon, H.J., Brown, M.S., and Goldstein, J.L. 2004. Direct binding of cholesterol to the purified membrane region of SCAP: mechanism for a sterol-sensing domain. Mol. Cell. 15:259-268.

13. Brown, A.J., Sun, L., Feramisco, J.D., Brown, M.S., and Goldstein, J.L. 2002. Cholesterol addition to ER membranes alters conformation of SCAP, the SREBP escort protein that regulates cholesterol metabolism. Mol. Cell. 10:237-245.

14. Adams, C.M., et al. 2004. Cholesterol and 25hydroxycholesterol inhibit activation of SREBPS by different mechanisms, both involving SCAP and insigs. J. Biol. Chem. 279:52772-52780.

15. Sever, N., Yang, T., Brown, M.S., Goldstein, J.L., and DeBose-Boyd, R.A. 2003. Accelerated degradation of HMG CoA reductase mediated by binding of Insig-1 to its sterol-sensing domain. Mol. Cell. 11:25-33.

16. Sever, N., et al. 2003. Insig-dependent ubiquitination and degradation of mammalian 3-hydroxy-3-methylglutaryl-CoA reductase stimulated by sterols and geranylgeraniol. J. Biol. Chem. 278:52479-52490.

17. Gil, G., Faust, J.R., Chin, D.J., Goldstein, J.L., and Brown, M.S. 1985. Membrane-bound domain of HMG CoA reductase is required for sterol-enhanced degradation of the enzyme. Cell. 41:249-258.

18. Roitelman, J., Olender, E.H., Bar-Nun, S., Dunn, W.A., Jr., and Simoni, R.D. 1992. Immunological evidence for eight spans in the membrane domain of 3-hydroxy-3-methylglutaryl coenzyme A reductase: implications for enzyme degradation in the endoplasmic reticulum. J. Cell Biol. 117:959-973.

19. Brown, M.S., and Goldstein, J.L. 1999. A proteolytic pathway that controls the cholesterol content of membranes, cells, and blood. Proc. Natl. Acad. Sci. U. S. A. 96:11041-11048.

20. Nakanishi, M., Goldstein, J.L., and Brown, M.S. 1988. Multivalent control of 3-hydroxy-3-methylglutaryl coenzyme A reductase: mevalonate-derived product inhibits translation of mRNA and accelerates degradation of enzyme. J. Biol. Chem. 263:8929-8937.

21. Lee, P.C.W., Sever, N., and DeBose-Boyd, R.A. 2005. Isolation of sterol-resistant Chinese hamster ovary cells with genetic deficiencies in both Insig- 1 and Insig-2. J. Biol. Chem. 280:25242-25249.

22. Sever, N., Lee, P.C.W., Song, B.-L., Rawson, R.B., and DeBose-Boyd, R.A. 2004. Isolation of mutant cells lacking Insig-1 through selection with SR-12813, an agent that stimulates degradation of 3-hydroxy3-methylglutaryl-coenzyme A reductase. J. Biol. Chem. 279:43136-43147.

23. Chen, G., Liang, G., Ou, J., Goldstein, J.L., and Brown, M.S. 2004. Central role for liver X receptor in insulin-mediated activation of Srebp-1c transcription and stimulation of fatty acid synthesis in liver. Proc. Natl. Acad. Sci. U. S. A. 101:11245-11250.

24. Yabe, D., Komuro, R., Liang, G., Goldstein, J.L., and Brown, M.S. 2003. Liver-specific mRNA for Insig-2 down-regulated by insulin: Implications for fatty acid synthesis. Proc. Natl. Acad. Sci. U. S. A. 100:3155-3160.

25. Engelking, L.J., et al. 2004. Overexpression of Insig-1 in the livers of transgenic mice inhibits SREBP processing and reduces insulin-stimulated lipogenesis. J. Clin. Invest. 113:1168-1175. doi:10.1172/JCI200420978.

26. Kuhn, R., Schwenk, F., Aguet, M., and Rajewsky, K. 1995. Inducible gene targeting in mice. Science. 269:1427-1429.

27. Repa, J.J., and Mangelsdorf, D.J. 2002. The liver X receptor gene team: potential new players in atherosclerosis [review]. Nat. Med. 8:1243-1248.

28. Brown, M.S., Brunschede, G.Y., and Goldstein, J.L. 1975. Inactivation of 3-hydroxy-3-methylglutaryl coenzyme A reductase in vitro: an adenine nucleotide-dependent reaction catalyzed by a factor in human fibroblasts. J. Biol. Chem. 250:2502-2509.

29. Sato, R., Goldstein, J.L., and Brown, M.S. 1993. Replacement of serine-871 of hamster 3-hydroxy-3methylglutaryl CoA reductase prevents phosphorylation by AMP-activated kinase and blocks inhibition of sterol synthesis induced by ATP depletion. Proc. Natl. Acad. Sci. U. S. A. 90:9261-9265.

30. Shimomura, I., Shimano, H., Horton, J.D., Goldstein, J.L., and Brown, M.S. 1997. Differential expression of exons $1 \mathrm{a}$ and $1 \mathrm{c}$ in mRNAs for sterol regulatory element binding protein- 1 in human and mouse organs and cultured cells. J. Clin. Invest. 99:838-845.

31. Repa, J.J., et al. 2000. Regulation of mouse sterol regulatory element-binding protein- $1 \mathrm{c}$ gene (SREBP-1c) by oxysterol receptors, LXR $\alpha$ and LXRß. Genes Dev. 14:2819-2830.

32. Horton, J.D., Goldstein, J.L., and Brown, M.S. 2002. SREBPs: activators of the complete program of cholesterol and fatty acid synthesis in the liver. J. Clin. Invest. 109:1125-1131. doi:10.1172/JCI200215593.

33. DeBose-Boyd, R.A., Ou, J., Goldstein, J.L., and Brown, M.S. 2001. Expression of sterol regulatory element-binding protein 1c (SREBP-1c) mRNA in rat hepatoma cells requires endogenous LXR ligands. Proc. Natl. Acad. Sci. U. S. A. 98:1477-1482. 34. Shimano, H., et al. 1996. Overproduction of cholesterol and fatty acids causes massive liver enlargement in transgenic mice expressing truncated SREBP-1a. J. Clin. Invest. 98:1575-1584.

35. Horton, J.D., et al. 1998. Activation of cholesterol synthesis in preference to fatty acid synthesis in liver and adipose tissue of transgenic mice overproducing sterol regulatory element-binding protein-2. J. Clin. Invest. 101:2331-2339.

36. Shimano, H., et al. 1997. Isoform 1c of sterol regulatory element binding protein is less active than isoform 1a in livers of transgenic mice and in cultured cells. J. Clin. Invest. 99:846-854.

37. Korn, B.S., et al. 1998. Blunted feedback suppression of SREBP processing by dietary cholesterol in transgenic mice expressing sterol-resistant SCAP(D443N). J. Clin. Invest. 102:2050-2060.

38. Matsuda, M., et al. 2001. SREBP cleavage-activating protein (SCAP) is required for increased lipid synthesis in liver induced by cholesterol deprivation and insulin elevation. Genes Dev. 15:1206-1216.

39. Yang, J., et al. 2001. Decreased lipid synthesis in livers of mice with disrupted Site-1 protease gene. Proc. Natl. Acad. Sci. U. S. A. 98:13607-13612.

40. Soriano, P., Montgomery, C., Geske, R., and Bradley, A. 1991. Targeted disruption of the c-src proto-oncogene leads to osteopetrosis in mice. Cell. 64:693-702.

41. Ishibashi, S., et al. 1993. Hypercholesterolemia in LDL receptor knockout mice and its reversal by adenovirus-mediated gene delivery. J. Clin. Invest. 92:883-893.

42. Liang, G., et al. 2002. Diminished hepatic response to fasting/refeeding and liver $\mathrm{X}$ receptor agonists in mice with selective deficiency of sterol regulatory element-binding protein-1c. J. Biol. Chem. 277:9520-9528.

43. Rohlmann, A., Gotthardt, M., Hammer, R.E., and Herz, J. 1998. Inducible inactivation of hepatic LRP gene by cre-mediated recombination confirms role of LRP in clearance of chylomicron remnants. J. Clin. Invest. 101:689-695.

44. Lakso, M., et al. 1996. Efficient in vivo manipulation of mouse genomic sequences at the zygote stage. Proc. Natl. Acad. Sci. U. S. A. 93:5860-5865.

45. Shimomura, I., et al. 1998. Insulin resistance and diabetes mellitus in transgenic mice expressing nuclear SREBP-1c in adipose tissue: model for congenital generalized lipodystrophy. Genes Dev. 12:3182-3194.

46. Luong, A., Hannah, V.C., Brown, M.S., and Goldstein, J.L. 2000. Molecular characterization of human acetyl CoA synthetase, an enzyme regulated by SREBPs. J. Biol. Chem. 275:26458-26466.

47. Shimomura, I., et al. 1997. Cholesterol feeding reduces nuclear forms of sterol regulatory element binding proteins in hamster liver. Proc. Natl. Acad. Sci. U. S. A. 94:12354-12359.

48. Shimano, H., et al. 1997. Elevated levels of SREBP-2 and cholesterol synthesis in livers of mice homozygous for a targeted disruption of the SREBP-1 gene. J. Clin. Invest. 100:2115-2124.

49. Sakai, J., et al. 1997. Identification of complexes between the COOH-terminal domains of sterol regulatory element binding proteins (SREBPs) and SREBP cleavage-activating protein (SCAP). J. Biol. Chem. 272:20213-20221.

50. Kita, T., Brown, M.S., and Goldstein, J.L. 1980. Feedback regulation of 3-hydroxy-3-methylglutaryl coenzyme A reductase in livers of mice treated with mevinolin, a competitive inhibitor of the reductase. J. Clin. Invest. 66:1094-1100. 